\title{
Satellite observations of long range transport of a large BrO plume in the Arctic
}

\author{
M. Begoin ${ }^{1}$, A. Richter ${ }^{1}$, M. Weber ${ }^{1}$, L. Kaleschke ${ }^{2}$, X. Tian-Kunze ${ }^{2}$, A. Stohl ${ }^{3}$, N. Theys ${ }^{4}$, and J. P. Burrows ${ }^{1}$ \\ ${ }^{1}$ Institute of Environmental Physics, University of Bremen, Bremen, Germany \\ ${ }^{2}$ Institute of Oceanography, University of Hamburg, Hamburg, Germany \\ ${ }^{3}$ Norwegian Institute for Air Research, Kjeller, Norway \\ ${ }^{4}$ Belgian Institute for Space Aeronomy, Brussels, Belgium
}

Received: 13 August 2009 - Published in Atmos. Chem. Phys. Discuss.: 30 September 2009

Revised: 2 June 2010 - Accepted: 22 June 2010 - Published: 16 July 2010

\begin{abstract}
Ozone Depletion Events (ODE) during polar springtime are a well known phenomenon in the Arctic and Antarctic boundary layer. They are caused by the catalytic destruction of ozone by halogens producing reactive halogen oxides like bromine monoxide $(\mathrm{BrO})$. The key halogen bromine can be rapidly transferred into the gas phase in an autocatalytic process - the so called "Bromine Explosion". However, the exact mechanism, which leads to an initial bromine release as well as the influence of transport and chemical processes on $\mathrm{BrO}$, is still not clearly understood.

In this study, $\mathrm{BrO}$ measurements from the satellite instrument GOME-2 are used together with model calculations with the dispersion model FLEXPART to study an arctic $\mathrm{BrO}$ event in March 2007, which could be tracked over several days and a large area. Full $\mathrm{BrO}$ activation was observed within one day east of Siberia with subsequent transport to Hudson Bay. The event was linked to a cyclone with very high surface wind speeds, which could have been involved in the production and lifting of aerosols or blowing snow. Considering the short life time of $\mathrm{BrO}$, transported aerosols or snow can also provide the surface for $\mathrm{BrO}$ recycling within the plume for several days. The evolution of the BrO plume could be reproduced by FLEXPART simulations of a passive tracer indicating that the activated air mass was transported all the way from Siberia to Hudson Bay. To localise the most probable transport height, model runs initialised in different heights have been performed showing similar transport patterns throughout the troposphere but best agreement with the measurements between the surface and $3 \mathrm{~km}$. The influence of changes in tropopause height on measured $\mathrm{BrO}$ values has
\end{abstract}

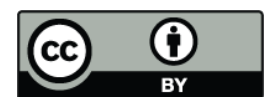

Correspondence to: $\mathrm{M}$. Begoin (begoin@iup.physik.uni-bremen.de) been considered, but cannot completely explain the observed high $\mathrm{BrO}$ values. Backward trajectories from the area of $\mathrm{BrO}$ initialisation show upward lifting from the surface up to $3 \mathrm{~km}$ and no indication for intrusion of stratospheric air. These observations are consistent with a scenario in which bromine in the air mass was activated on the surface within the cyclone, lifted upwards and transported over several thousand kilometres to Hudson Bay.

\section{Introduction}

Strong depletion of tropospheric ozone in the Arctic polar boundary layer in spring was first reported in the 1980s at Barrow, Alaska (Oltmans, 1981) and Alert, Canada (Bottenheim et al., 1986). Later, measurements in the Antarctic at McMurdo (Sturges et al., 1993), Neumayer (Wessel et al., 1998), Syowa (Murayama et al., 1992) and Arrival Heights (Kreher et al., 1997) and at many other Arctic and Antarctic stations, demonstrated that ODEs are a regular feature in the polar atmosphere. The importance of halogens for these events was suggested and validated by a clear correlation between low ozone and high values of filterable bromine (Barrie et al., 1989). Based on these data, a dominating bromine radical-catalysed cycle involving $\mathrm{Br}$ and $\mathrm{BrO}$ radicals was suggested to explain the destruction of ozone (Barrie et al., 1988). The occurrence of such ozone depletion events, lasting from a few hours to several days, is limited to the polar boundary layer in springtime and has been linked to low temperatures and the presence of sufficient sunlight. Under these conditions, bromine is believed to be released from sea salt to the gas phase by different photochemical and heterogeneous reactions. The following autocatalytic sequence of reactions

Published by Copernicus Publications on behalf of the European Geosciences Union. 
is the so called "Bromine Explosion" (Platt and Lehrer, 1996) which rapidly releases bromine from the liquid to the gas phase and explains the occurrence of the observed high $\mathrm{BrO}$ and low ozone values.

$$
\begin{aligned}
\mathrm{HOBr}+\mathrm{H}^{+}+\mathrm{Br}^{-} & \rightarrow \mathrm{H}_{2} \mathrm{O}+\mathrm{Br}_{2} \\
\mathrm{Br}_{2}+h v & \rightarrow 2 \mathrm{Br} . \\
\mathrm{Br} \cdot+\mathrm{O}_{3} & \rightarrow \mathrm{BrO} \cdot+\mathrm{O}_{2} \\
\mathrm{BrO} \cdot+\mathrm{HO}_{2} & \rightarrow \mathrm{HOBr}+\mathrm{O}_{2}
\end{aligned}
$$

$\mathrm{H}^{+}+\mathrm{Br}^{-}+\mathrm{HO}_{2}+\mathrm{O}_{3} \rightarrow \mathrm{Br} \cdot+\mathrm{H}_{2} \mathrm{O}+2 \mathrm{O}_{2}$

The first of the equations represents the heterogeneous reaction, which is required for initial release of gaseous bromine to the atmosphere. It can possibly proceed on surfaces with enriched concentrations of sea salt like young sea ice (Frieß et al., 2004; Simpson et al., 2007), sea salt aerosols (Vogt et al., 1996), frost flowers or aerosol from frost flowers (Kaleschke et al., 2004), sea salt deposited on ice or snow (McConnell et al., 1992) or blown snow which is enriched in sea salt (Yang et al., 2008).

The production of reactive bromine species leads to an exponential growth of $\mathrm{BrO}$ radicals in the atmosphere, which can be measured in situ or by absorption spectroscopy from the ground (Hausmann and Platt, 1994; Frieß et al., 2004) and from space (Platt and Wagner, 1998; Richter et al., 1998). Ground based BrO measurements show good correlation with depleted ozone concentrations (Hönninger and Platt, 2002; Lehrer et al., 1997). In satellite measurements, enhanced $\mathrm{BrO}$ is mainly observed above areas covered by sea ice (Richter et al., 2002; Wagner et al., 2001). Due to their high reactivity, BrO radicals have a very short atmospheric lifetime and should vanish quickly from the atmosphere by consecutive reactions. Ground-based observations of ODEs and $\mathrm{BrO}$ events are often limited to a few hours, but also multi-day events can be observed. However, $\mathrm{BrO}$ plumes can be observed in satellite data for many days and over large areas, suggesting additional chemical mechanisms and the transport of the involved air masses.

To date it is not clear whether these large-scale plumes indicate continuous generation of $\mathrm{BrO}$ from the surface as an air mass traverses the source region, or whether the high $\mathrm{BrO}$ levels can be sustained in the air as it is transported away from surface sources of bromine. Large $\mathrm{BrO}$ columns in the satellite observations could also result from increases in stratospheric $\mathrm{BrO}$ column when the tropopause is unusually low. A clear anti-correlation between tropopause height and ozone columns was found in many studies (e.g. Hoinka (1996); Schubert et al. (1988)) and the same effect could also explain enhanced $\mathrm{BrO}$ columns in situations with a low tropopause.

In this paper, we analyse an individual large $\mathrm{BrO}$ event observed by the GOME-2 instrument in March 2007. The sequence of satellite measurements is used to study the spatial and temporal evolution of the event and is compared to transport simulations by the FLEXPART particle dispersion model (Stohl et al., 1998). To investigate the vertical distribution and origin of the $\mathrm{BrO}$, several model runs initialised in different altitudes (boundary layer, lower troposphere, upper troposphere, lower stratosphere) were performed. A possible influence of stratospheric air masses on the high $\mathrm{BrO}$ values observed was investigated with data on tropopause heights and total ozone columns as well as backward trajectories.

\section{Methods}

\subsection{GOME-2 BrO and ozone data}

GOME-2 (Global Ozone Monitoring Experiment-2) is a $\mathrm{UV} /$ vis nadir-viewing grating spectrometer that measures the solar radiation scattered and reflected by the atmosphere (Callies et al., 2000). It was launched into a polar sunsynchronous orbit on the MetOp-A satellite (Meteorological Operational satellite-A) in October 2006 and has an equator crossing time of $9.30 \mathrm{~h}$ local time. With a spatial resolution of $40 \times 80 \mathrm{~km}^{2}$ and a scan width of $1920 \mathrm{~km}$, global coverage is achieved within one day and several measurements per day are available at high latitudes under daylight conditions. GOME- 2 measures in the wavelength range between 240 and $790 \mathrm{~nm}$ with a spectral resolution between 0.2 and $0.4 \mathrm{~nm}$. BrO retrievals using GOME-2 data have already been used in previous studies, e.g. investigating $\mathrm{BrO}$ in a volcanic plume (Theys et al., 2009a).

Retrieval of tropospheric $\mathrm{BrO}$ columns is performed in three steps: First, the $\mathrm{BrO}$ amount along the line of sight is determined using the well known Differential Optical Absorption Spectroscopy (DOAS) method (Platt, 1994). From this column, an estimate of the stratospheric contribution is subtracted and the resulting tropospheric column then converted into a tropospheric vertical column.

For spectral analysis, a fitting window of 336 to $347 \mathrm{~nm}$ has been used as in the analysis of SCIAMACHY measurements (Afe et al., 2004). In the fit, the absorption crosssections of $\mathrm{O}_{3}(223 \mathrm{~K}$ and $273 \mathrm{~K}), \mathrm{NO}_{2}(223 \mathrm{~K})$ and $\mathrm{BrO}$ are included as well as a Ring-pseudo-spectrum for correction of the effect of Rotational Raman scattering and a polynomial of order 4 . The result of this analysis is the slant column SC which comprises both the tropospheric and stratospheric BrO. To account for the influence of stratospheric $\mathrm{BrO}$, a correction has been performed using data from the stratospheric $\mathrm{BrO}$ climatology developed by Theys et al. (2009b). This approach is based on a parameterisation using dynamical and chemical indicators together with output data from the 3-D chemistry transport model BASCOE (http://bascoe.oma.be). The BASCOE model includes all relevant chemical reactions in the stratosphere. Changes in $\mathrm{BrO}$ distribution due to stratospheric dynamics are taken 
into account by a parameterisation based on measured ozone columns while $\mathrm{NO}_{2}$ columns are used to deal with photochemical changes in $\mathrm{BrO} / \mathrm{Br}_{\mathrm{y}}$ ratios. The climatology has been optimised for bromine chemistry and budget and validated through comparisons using ground-based, balloonborne and satellite limb (SCIAMACHY) stratospheric $\mathrm{BrO}$ observations. Compared to the changes in observed $\mathrm{BrO}$ values around $1.5 \times 10^{14} \mathrm{molec} / \mathrm{cm}^{2}$, stratospheric $\mathrm{BrO}$ climatology data only show small variations between 2.5$4.5 \times 10^{13} \mathrm{molec} / \mathrm{cm}^{2}$. The error budget of the stratospheric columns is estimated to be about $15 \%$. As it is based on climatological relations, in cases of unusually low tropopause height climatology data could slightly underestimate the stratospheric column.

For the determination of $\mathrm{BrO}$ tropospheric vertical columns (VC), different Air Mass Factors (AMF) were calculated, assuming all $\mathrm{BrO}$ to be well mixed in a boundary layer of $400 \mathrm{~m}$ or located in a $1 \mathrm{~km}$ thick layer at $2 / 4 / 6 / 8 / 10 \mathrm{~km}$, respectively. A surface albedo of 0.9 was used for the radiative transfer calculations as the measurements are performed over ice.

Clouds can interfere with the retrieval of $\mathrm{BrO}$ by shielding lower tropospheric $\mathrm{BrO}$ from view below a thick cloud and by enhancing the sensitivity to $\mathrm{BrO}$ above and within a cloud, in particular for optically thin clouds. The shielding effect is much less pronounced over snow and ice than over dark surfaces and up to cloud optical thickness of 20 , the sensitivity of the measurements to boundary layer $\mathrm{BrO}$ might actually increase in the presence of clouds. In this study, GOME$2 \mathrm{BrO}$ data have not been corrected for clouds as detailed cloud information over the polar region is not available at the time and location of measurements. This introduces some uncertainty and should be improved upon in future studies.

In this study we also use total ozone retrieved from GOME-2 data using the WFDOAS (Weighting Function DOAS) algorithm (Coldewey-Egbers et al., 2005; Weber et al., 2007) to investigate the possibility of stratospheric influences on the retrieved BrO columns (Section 4.2).

\subsection{FLEXPART model simulations}

FLEXPART is a Lagrangian particle dispersion model that simulates the long-range and mesoscale transport and diffusion of atmospheric tracers as well as loss processes such as dry and wet deposition or radioactive decay (Stohl et al., 2005). FLEXPART has been validated against large scale tracer experiments (Stohl et al., 1998).

In this study, FLEXPART is used to simulate the transport of two BrO plumes. The model was driven by operational meteorological analyses from the European Centre for Medium-Range Weather Forecasts (ECMWF) with a horizontal resolution of 1 degree, a vertical resolution of 91 pressure levels and a temporal resolution of $3 \mathrm{~h}$. The model output has a resolution of 0.5 degree and a temporal resolution of 1 hour. FLEXPART was initialised with the observed dis- tribution of $\mathrm{BrO}$ at a particular time in different altitudes, and thereafter $\mathrm{BrO}$ was treated as a passive tracer that was tracked for about two weeks.

\section{Results}

The $\mathrm{BrO}$ event investigated here started on 25 March in Laptev and East Siberian Sea and reached its maximum on 26 March with highest tropospheric $\mathrm{BrO}$ values around $1.5 \times 10^{14} \mathrm{molec} / \mathrm{cm}^{2}$, if all $\mathrm{BrO}$ is assumed to be located and well mixed in the boundary layer below $400 \mathrm{~m}$ (Fig. 1). The days before, $\mathrm{BrO}$ values were significantly lower over the Arctic Ocean sea ice. Observations with the GOME-2 instrument indicate a fast transport of the fully developed BrO plume from 26 March over the following 3 days towards Hudson Bay. On 30 March the GOME-2 instrument was operated in narrow swath mode, which increases the spatial resolution but reduces coverage.

\subsection{Meteorological situation}

On 26 March 2007, a cyclone covered large parts of the Arctic Ocean, extending from the Laptev Sea to the North Pole. High surface wind speeds and low temperatures (Fig. 2) were associated with this cyclone. High $\mathrm{BrO}$ concentrations were first observed especially in the southern part of the cyclone north of Laptev Sea where surface wind speeds were highest. This suggests that these high wind speeds could be involved in the initial release of $\mathrm{BrO}$ but higher solar insolation at lower latitudes could also contribute. Over the next few days, the cyclone weakened while travelling eastwards. On $28 \mathrm{March}$, it was centered over the Beaufort Sea north of Alaska and Canada. Wind speeds were still high just north of Alaska/Canada but weakened substantially on 29 March. Since the BrO plume first appeared on 25/26 March in the southern part of the cyclone where strong westerly winds prevailed and also the cyclone tracked eastward over the following days, the air mass containing the high $\mathrm{BrO}$ is expected to have travelled eastward towards Alaska/Canada, too.

\subsection{FLEXPART model simulations}

To localise the most likely initial $\mathrm{BrO}$ source in time and space, all single satellite orbits have been analysed in detail. Owing to its large swath, GOME-2 provides several overpasses over each location at high latitudes per day at this season. The event appears to have started in two different, clearly separated regions. Three orbits were identified as covering the region of $\mathrm{BrO}$ initialisation, one for the first event and two consecutive orbits which have to be combined to completely cover the second source region (Fig. 3). To extract the most probable source region for the $\mathrm{BrO}$ events, a threshold was applied to the tropospheric $\mathrm{BrO}$ fields and only values above $5.0 \times 10^{13} \mathrm{molec} / \mathrm{cm}^{2} \mathrm{BrO} \mathrm{VC}$ were used. The exact time of $\mathrm{BrO}$ initialisation cannot be determined 

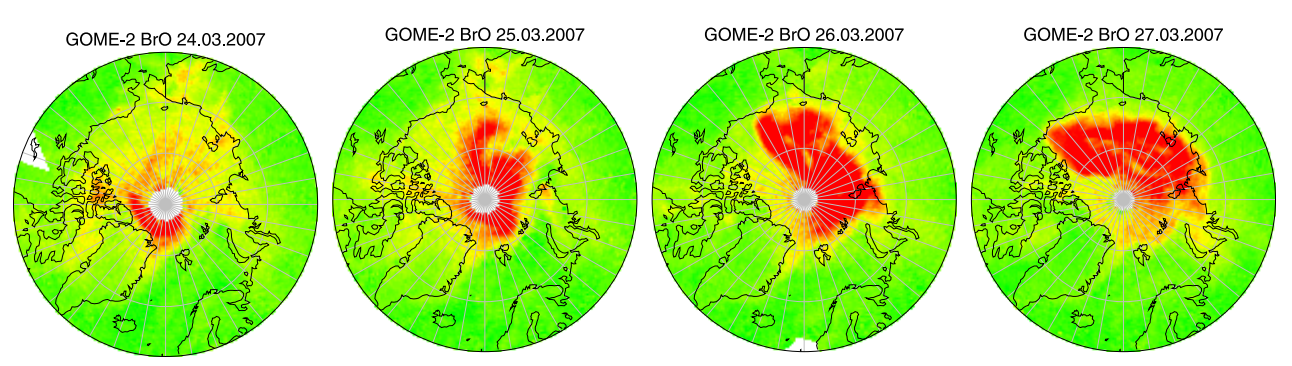

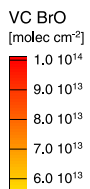
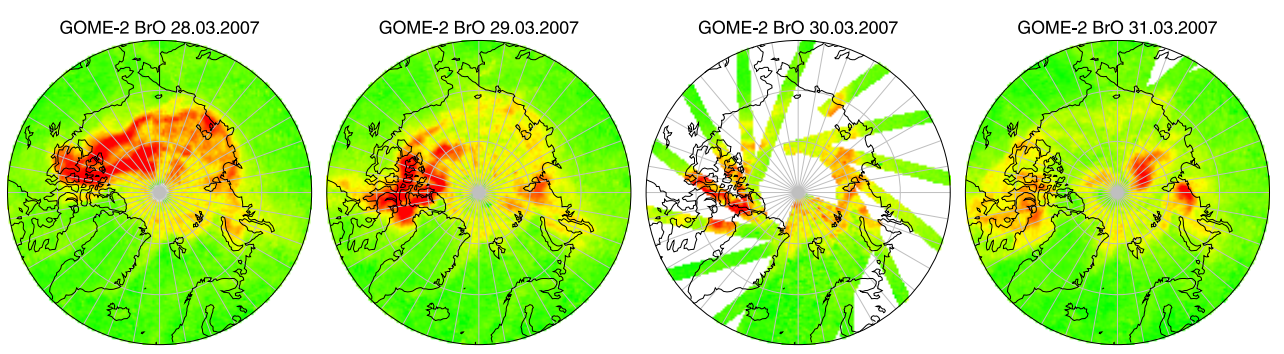

Fig. 1. Daily averaged vertical column of GOME-2 tropospheric BrO measurements corrected by stratospheric climatology data. For the radiative transfer calculations, BrO was assumed to reside in the lowest $400 \mathrm{~m}$. Enhanced values on $25 \mathrm{March}$ in East Siberian Sea result from the last orbit of that day at 22:44 UTC. The following orbit on 26 March at 00:26 UTC (Fig. 3) was used as one input for the FLEXPART model run. On 30 March GOME-2 was operated in narrow swath mode.
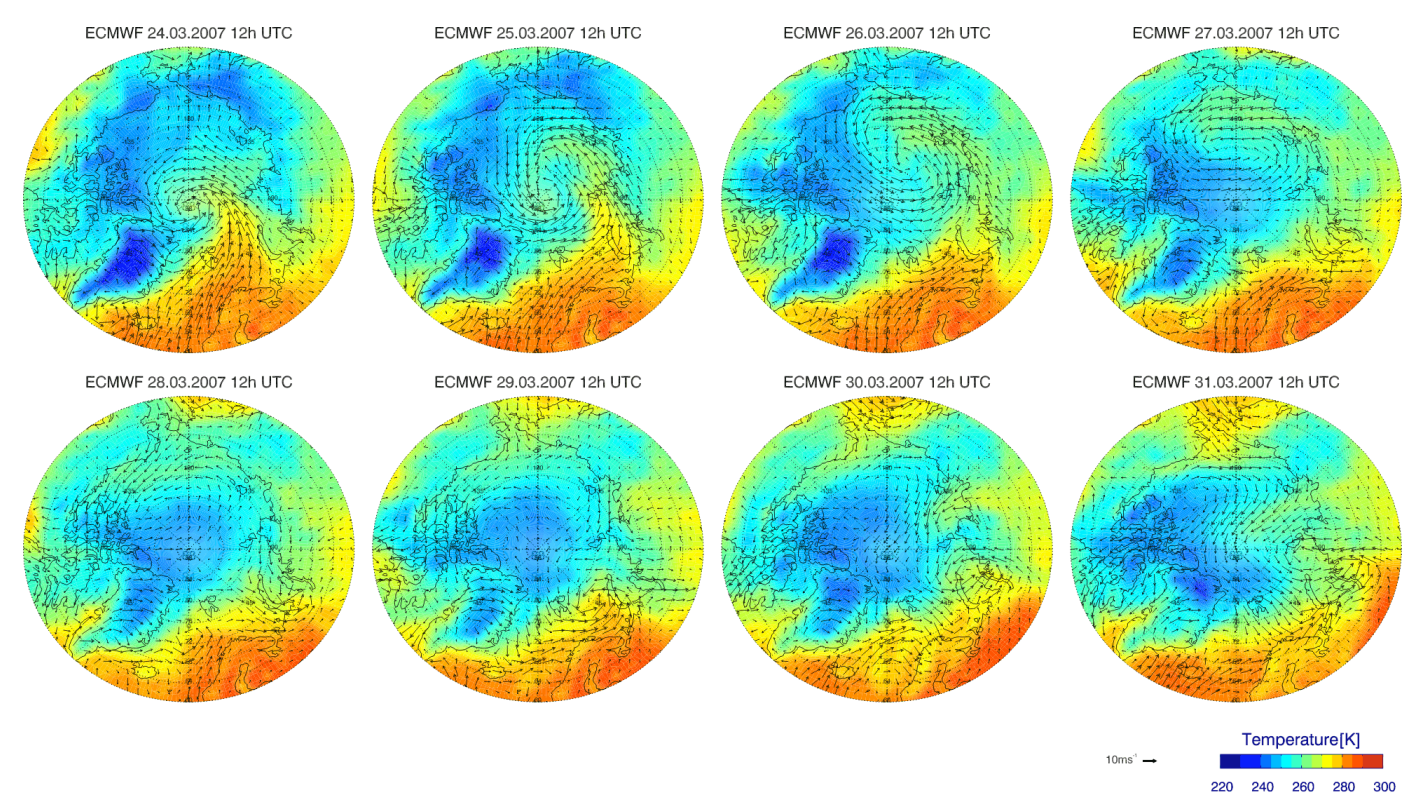

Fig. 2. ECMWF data, showing surface temperatures and wind fields during the BrO event (12:00 h UTC).

from the satellite measurements. The process must have started some time between the measurement on 25 of March, when $\mathrm{BrO}$ was still low and the highest observations on 26 March. At that time, the BrO plume had already expanded and moved away from the initial source region through transport. The fully evolved BrO distribution on 26 March derived in this way was then used as input for a FLEXPART simulation. The $\mathrm{BrO}$ distribution was remapped to a resolution of $0.5^{\circ} \times 0.5^{\circ}$ and FLEXPART was initialised with the observed concentrations in these grid cells at the time of observation. Because the exact distribution of $\mathrm{BrO}$ within the atmosphere is not known, several FLEXPART model runs have been initialised in different altitudes to get information on the potential origin of the observed $\mathrm{BrO}$ enhanced air masses. For these model runs all tropospheric $\mathrm{BrO}$ is assumed to be located within different layers of the atmosphere $(0-1 \mathrm{~km} / 1-$ $3 \mathrm{~km} / 3-5 \mathrm{~km} / 5-7 \mathrm{~km} / 7-9 \mathrm{~km} / 9-11 \mathrm{~km})$ and in the comparison to GOME-2 data, a corresponding AMF for the $\mathrm{BrO}$ amount 
GOME-2 BrO 26.03.2007 00:26 UTC

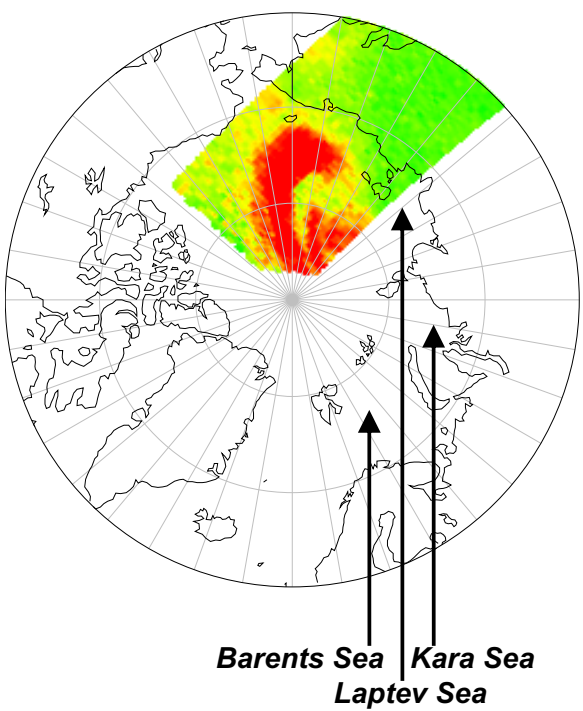

GOME-2 BrO 26.03.2007 03:50/07:17 UTC

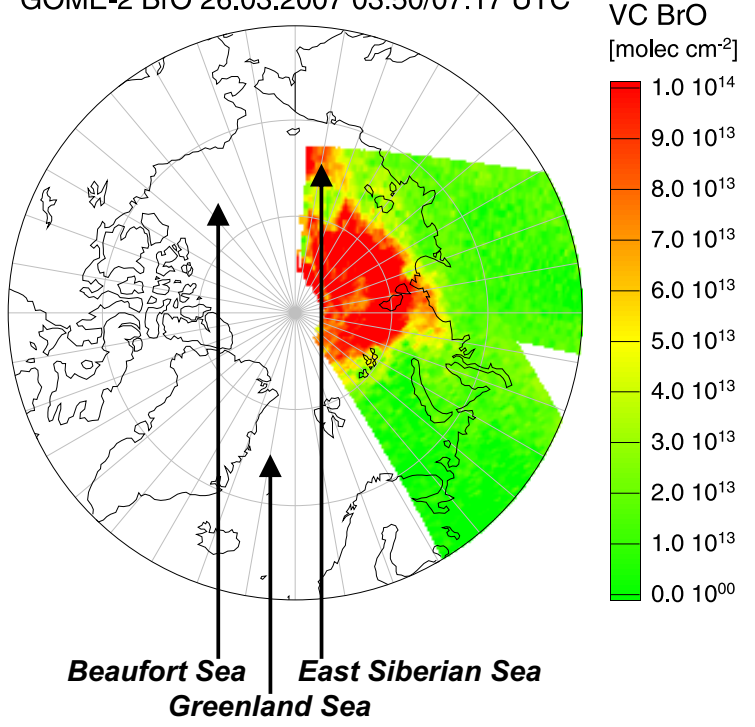

Fig. 3. Above figures show three satellite orbits, which have been used as input to initialise the FLEXPART model calculations. For the second source region, two orbits have been combined to cover the complete $\mathrm{BrO}$ plume.

was used. Subsequently, the $\mathrm{BrO}$ was treated as a passive tracer that was transported by the ECMWF resolved winds as well as turbulence and convection parameterisations.

To facilitate comparison with the satellite measurements, the $1 \mathrm{~h}$ FLEXPART model output had to be integrated vertically and sampled in a similar way as the daily averaged GOME-2 data. In a first step, each satellite orbit was matched with the FLEXPART model output closest in time and location. In the second step, each FLEXPART output chosen was masked spatially with its corresponding GOME-2 orbit. Finally, the preprocessed FLEXPART data were combined in a single composite to get daily averaged data comparable to GOME-2 satellite measurements. This was done for all FLEXPART model runs. Due to the mentioned clear separation in time and space of the two observed $\mathrm{BrO}$ events, the model results were added to create the final FLEXPART average to be compared to GOME-2 satellite data.

As with the GOME-2 measurements, all daily averaged FLEXPART results below $9 \mathrm{~km}$ show rapid transport of the passive $\mathrm{BrO}$ tracer towards Hudson Bay within three days (Fig. 4). Above this altitude, the transport pattern shows substantial deviations from GOME-2 measurements and no transport towards Hudson Bay. Further, runs below $3 \mathrm{~km}$ show enhanced $\mathrm{BrO}$ values in the Laptev Sea on 29 March, which can't be seen in GOME-2 data. Above $3 \mathrm{~km}$, model runs show export of $\mathrm{BrO}$ to low latitudes into Bering Sea on 26 March and transport of $\mathrm{BrO}$ from Hudson Bay over northern Greenland into the Barents Sea on 31 March 5. Both patterns are not observed in GOME-2 measurements. In all FLEXPART simulations from 26 until 31 March, the BrO tracer remains more or less at constant height throughout transport.

\section{Discussion}

\subsection{Comparison of GOME-2 BrO with FLEXPART model data}

The fast transport of $\mathrm{BrO}$ towards Hudson Bay observed in GOME-2 data can be seen as well in all FLEXPART model runs below $9 \mathrm{~km}$ altitude (Fig. 4). The transport patterns look quite similar but show differences in absolute values and some transport features are not seen in every model run (Transport into Bering Sea on $26 \mathrm{March} /$ Higher $\mathrm{BrO}$ in Laptev Sea on 29 March/Transport over Northern Greenland into Barents Sea on 31 March (Fig. 5)). Nevertheless, the troposphere and lower stratosphere show similar dynamics during this special event. Above $9 \mathrm{~km}$ FLEXPART model runs show larger deviations from GOME-2 measurements, but below no specific altitude is clearly favoured by the model results within the first days of the event. Analysis of the daily linear correlation coefficient between measured and modelled $\mathrm{BrO}$ columns north of $60^{\circ} \mathrm{N}$ shows that the correlation between both remains high for several days and that best agreement is found for a FLEXPART initialisation between 1 and $3 \mathrm{~km}$ and $0-1 \mathrm{~km}$ (Fig. 6). This lower tropospheric location of the $\mathrm{BrO}$ is further confirmed by the rapid transport of $\mathrm{BrO}$ over Northern Greenland into the Barents Sea predicted by all FLEXPART runs initialised above $3 \mathrm{~km}$ altitude which is not seen in GOME-2 measurements.

\subsection{Possible influence of stratospheric air}

Strong changes in tropopause height can have an influence on the satellite measured $\mathrm{BrO}$ values as they impact on the stratospheric $\mathrm{BrO}$ column. As the tropopause descends and 

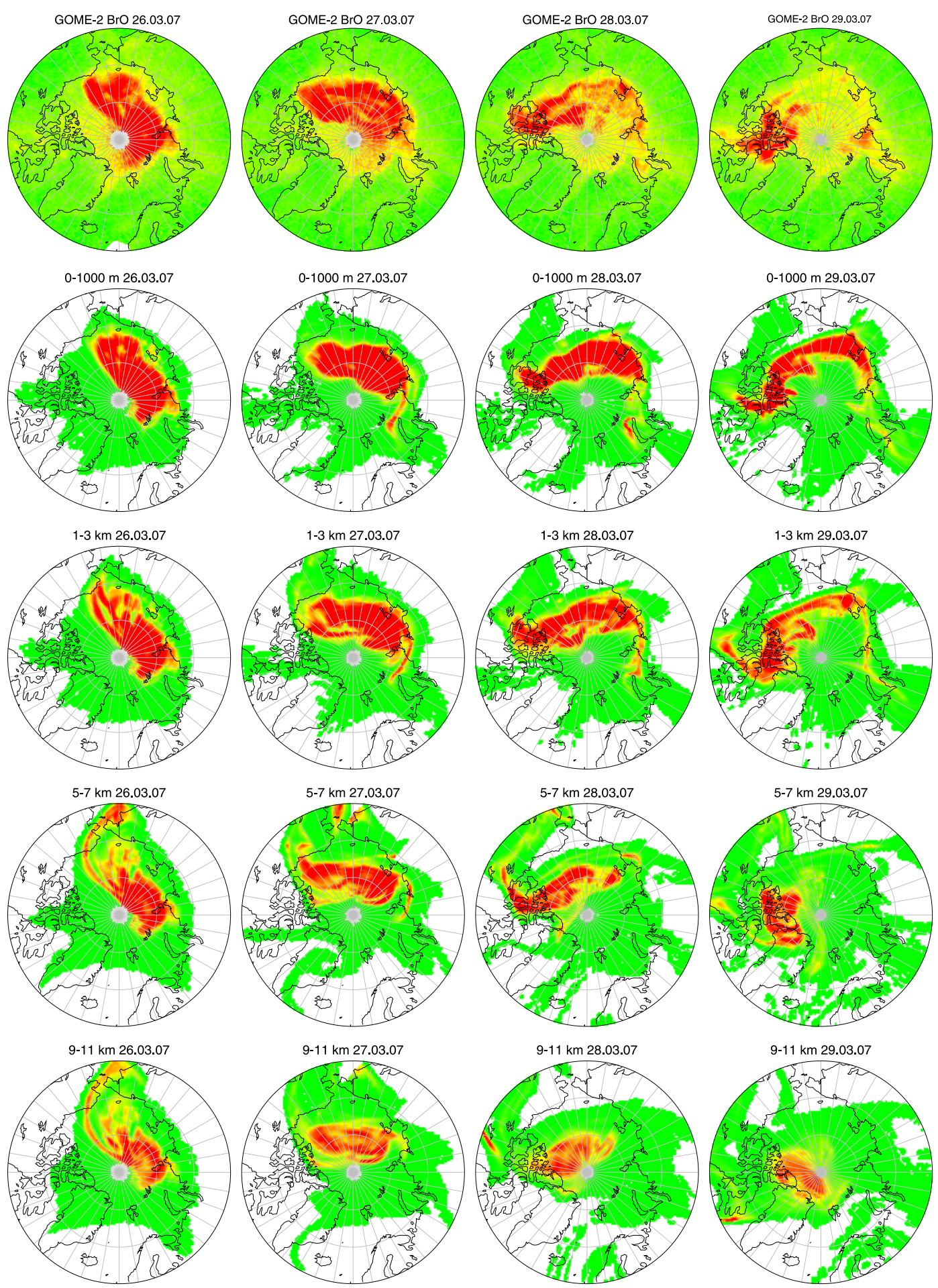

$0.010^{00} 2.010^{13} \quad 4.010^{13} \quad 6.010^{13} \quad 8.010^{13} \quad 1.010^{14}$ $\mathrm{VC} \mathrm{BrO}\left[\mathrm{molec} \mathrm{cm}^{-2}\right]$

Fig. 4. Daily averaged FLEXPART model results adjusted to GOME-2 measurement data (26-29 March 2007). On top stratospheric corrected GOME-2 measurement data using boundary layer AMF (400 m) are shown. 

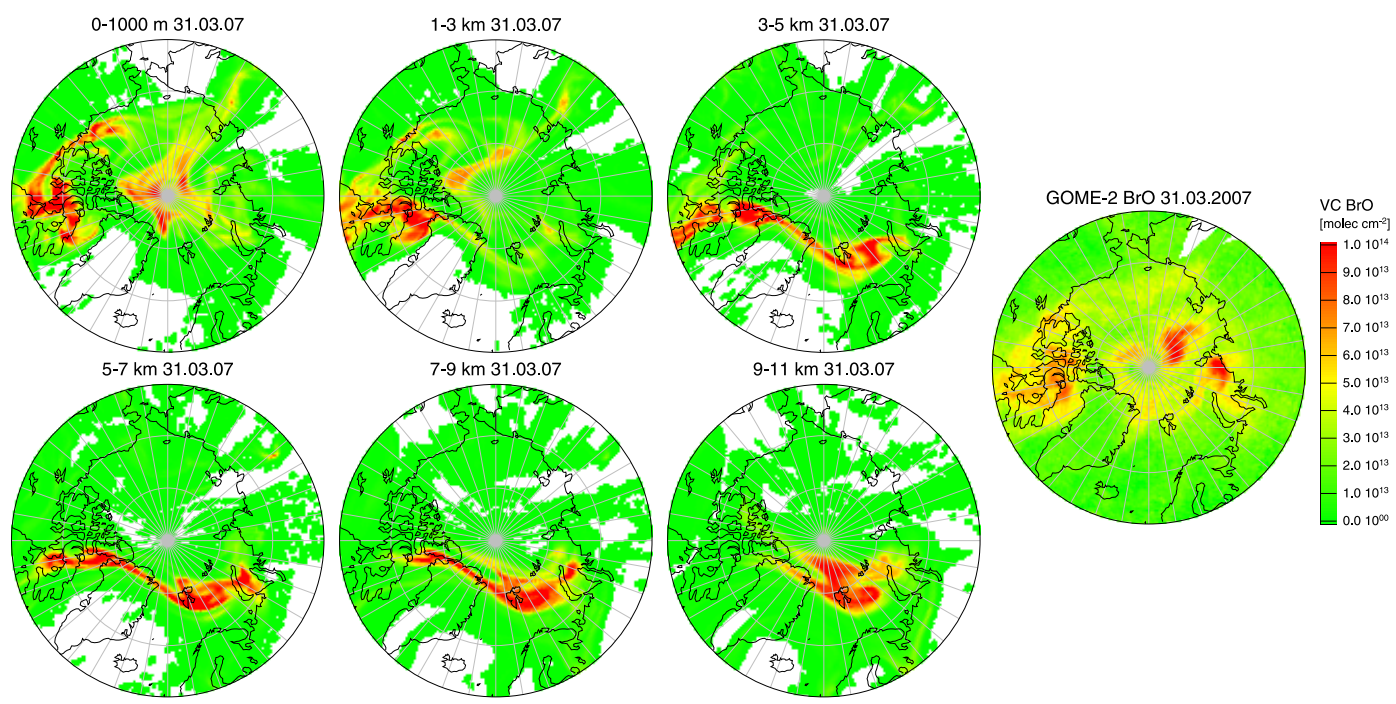

Fig. 5. FLEXPART model results for different initialisation heights on 31 March compared to GOME-2 measurments. Model runs above $3 \mathrm{~km}$ show transport over Greenland not seen in GOME-2 BrO

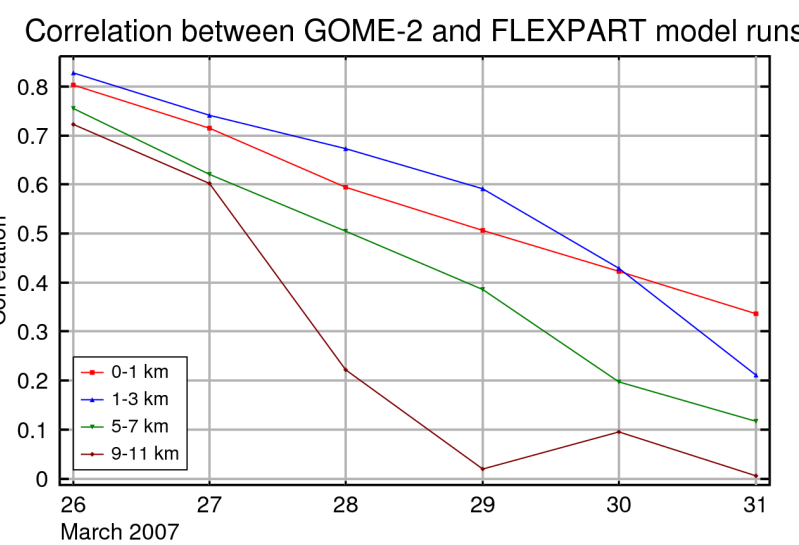

Fig. 6. Spatial correlation between GOME-2 BrO data and FLEXPART model runs compared for different initialisation heights. All data North of $60^{\circ}$ was used.

$\mathrm{BrO}$ rich air sinks to lower levels, the stratospheric $\mathrm{BrO}$ column increases. If not accounted for, this can lead to significant overestimation of tropospheric $\mathrm{BrO}$ values. As is illustrated in Fig. 7, the $\mathrm{BrO}$ event was at least partly linked to low tropopause heights so this effect needs to be considered. Assuming a simplified initial stratospheric $\mathrm{BrO}$ profile with a linear increase from 10 to $20 \mathrm{~km}$ (VMR: 0-15 ppt) and constant values above, a descent of stratospheric air by $5 \mathrm{~km}$ would lead to an increase of the $\mathrm{BrO}$ column by $85 \%$ or $3 \times 10^{13} \mathrm{molec} / \mathrm{cm}^{2}$ if this $\mathrm{BrO}$ is not converted into bromine reservoirs. While this is a significant effect, it could still not completely explain the observed high $\mathrm{BrO}$ columns around $1.5 \times 10^{14} \mathrm{molec} / \mathrm{cm}^{2}$. It should also be pointed out that the stratospheric $\mathrm{BrO}$ climatology applied will correct a large part of the tropopause change related to $\mathrm{BrO}$ increase through the GOME-2 measured ozone column. However, as shown in Fig. 7, ozone columns were not particularly high during the event and therefore stratospheric $\mathrm{BrO}$ in the climatology does not show enhanced stratospheric values in this area.

The link between tropopause height, $\mathrm{BrO}$, and ozone is further investigated by scatter plots of these variables for all data above $60^{\circ} \mathrm{N}$ during the first day of the $\mathrm{BrO}$ event (Fig. 8). Tropopause heights have been extracted from ECMWF data (horizontal resolution 0.5 degree/temporal resolution $6 \mathrm{~h}$ ) using a potential vorticity surface of $2 \mathrm{PVU}$ (courtesey of Andreas Dörnbrack, DLR) and have been allocated to corresponding GOME-2 orbits in the same way as FLEXPART model results. Ozone columns show the expected correlation with tropopause height, the largest values being observed at low tropopause height. The link is not as clear as in mid-latitude studies, perhaps a result of the complicating impact of chemical ozone depletion in the springtime ozone fields. Comparison of tropopause height and $\mathrm{BrO}$ columns shows, that enhanced $\mathrm{BrO}$ values above $1.0 \times 10^{14}$ are always associated with lower tropopause heights between $5-9 \mathrm{~km}$. This suggests an influence of tropopause height on $\mathrm{BrO}$ values. On the other hand, low tropopause is by no means always correlated with enhanced $\mathrm{BrO}$ values which can also be seen in Fig. 7 where many regions of low tropopause do not have corresponding high $\mathrm{BrO}$ columns. Therefore, low tropopause alone cannot be the explanation for the high $\mathrm{BrO}$.

There are several possible explanations for the observed complex link between $\mathrm{BrO}$ and tropopause height:

1. The climatology data could possibly predict too low stratospheric BrO columns for these special weather conditions, leading to an overestimation of tropospheric 

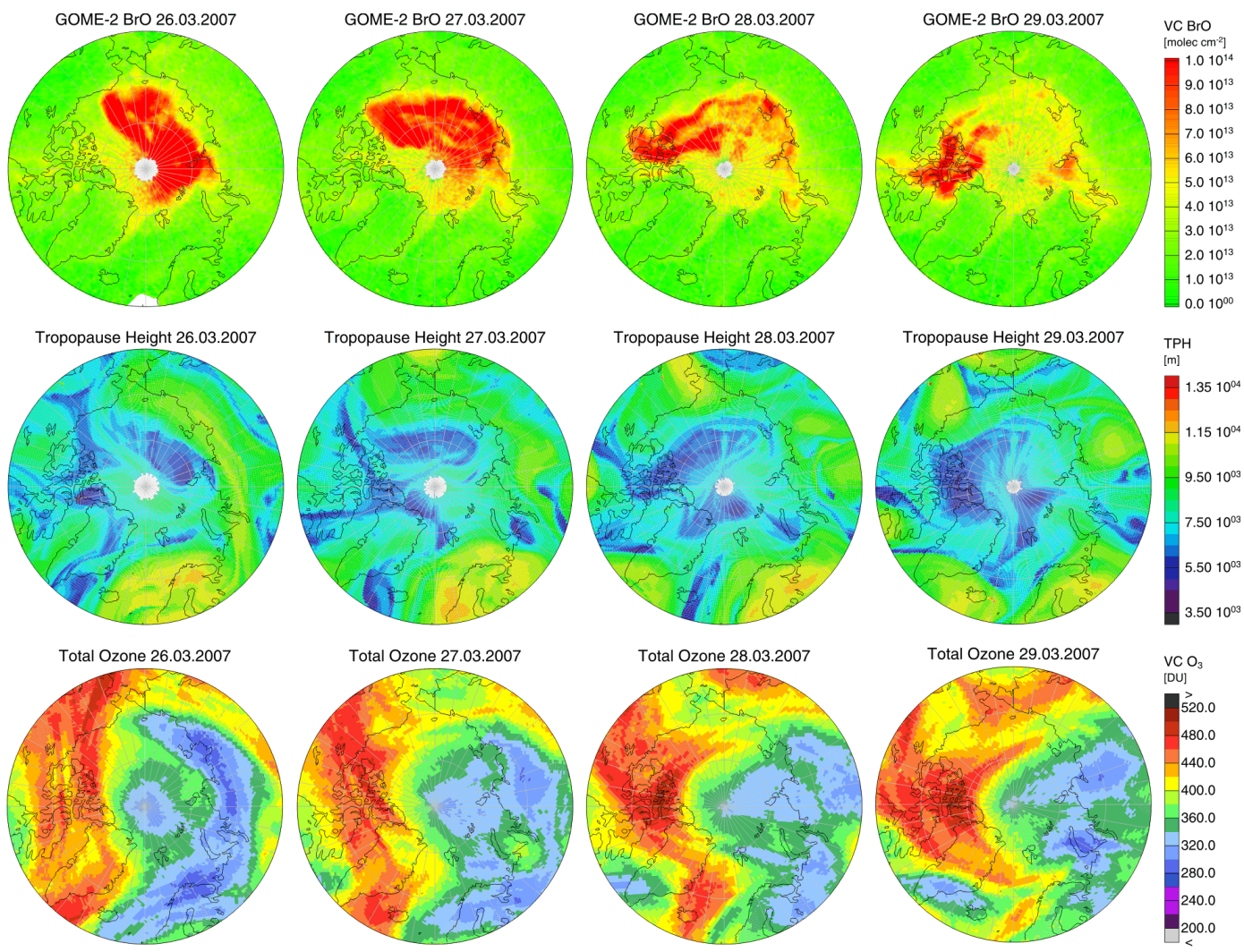

$\mathrm{VCO}_{3}$
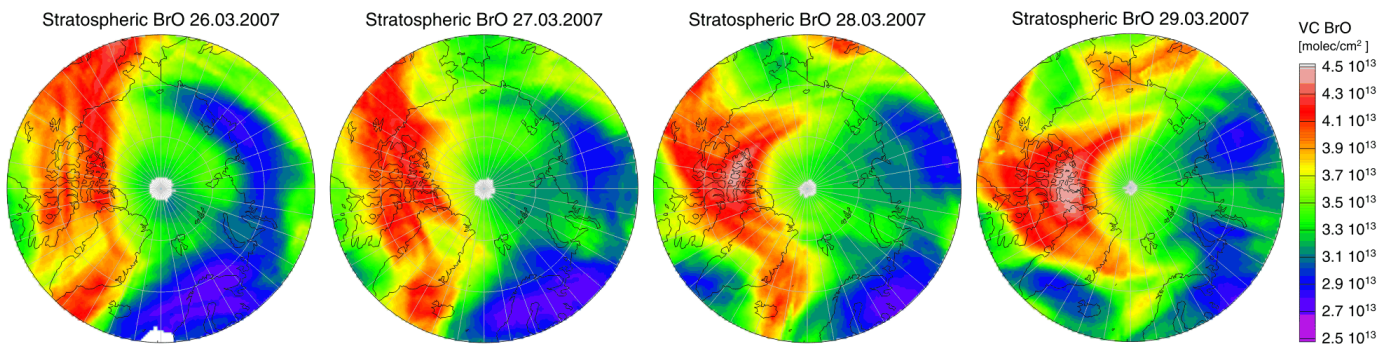

Fig. 7. Stratosphere corrected GOME-2 BrO (AMF $2000 \mathrm{~m}$ ) in comparison to Total Ozone(GOME-2), Tropopause Height (ECMWF data adjusted to GOME-2 orbits-courtesey of Andreas Dörnbrack, DLR) and stratosperic BrO climatology data.


Fig. 8. Scatter plots of total ozone, tropopause height and tropospheric BrO from GOME-2 

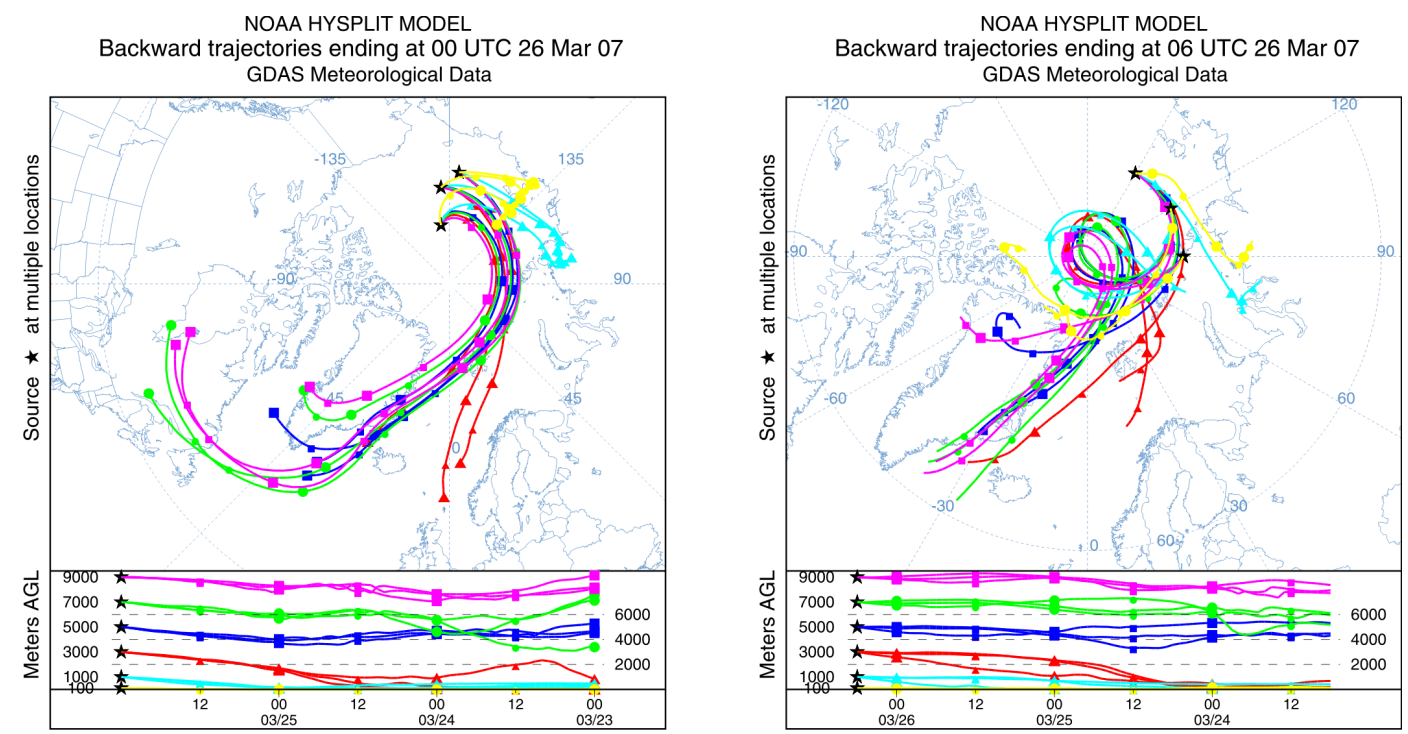

Fig. 9. HYSPLIT $72 \mathrm{~h}$ backward trajectories started within the FLEXPART initialisation plumes.

$\mathrm{BrO}$ in the presence of low tropopause heights. This effect should not be larger than $1.0 \times 10^{13} \mathrm{molec} / \mathrm{cm}^{2}$.

2. High BrO columns could depend on a different process which is linked to low tropopause heights. In the case discussed here, this could be the strong low pressure system which could have activated the $\mathrm{BrO}$ at the surface and lifted it up and at the same time have lead to a low tropopause height. This would imply that a low tropopause is not the reason for the $\mathrm{BrO}$ enhancement but just a by-product of the storm.

3. A low tropopause height in combination with the low pressure system could have lead to a stratospheric intrusion inserting $\mathrm{BrO}$ rich stratospheric air into the troposphere.

The third possibility is investigated by analysing backward trajectories from the region of $\mathrm{BrO}$ initialisation. If a stratospheric intrusion were responsible for the observed $\mathrm{BrO}$ enhancement, a strong downward motion should be apparent in the trajectories bringing stratospheric $\mathrm{BrO}$ into the lower troposphere. However, as shown in Fig. 9, backward trajectories calculated with the HYSPLIT (HYbrid Single-Particle Lagrangian Integrated Trajectory) model (Draxler and Rolph, 2005) initialised on 26 March within the two source regions (Fig. 3) do not indicate an intrusion. On the contrary, they show upward transport of surface air to altitudes of up to $3 \mathrm{~km}$, in agreement with the results of the FLEXPART comparison which shows best agreement with GOME-2 data for $\mathrm{BrO}$ mixed up to this altitude.

Based on the results of the FLEXPART simulations, the correlations between $\mathrm{BrO}$, ozone and tropopause height and the backward trajectories from the initialisation area we conclude that the most probable explanation of the observed $\mathrm{BrO}$ plume is activation of $\mathrm{BrO}$ or precursors on the surface at very high wind speeds, upward transport to $3 \mathrm{~km}$ within the low pressure system and subsequent transport of the $\mathrm{BrO}$ rich air mass towards Hudson Bay in an altitude between the surface and $3 \mathrm{~km}$.

\subsection{Long range transport and life time of $\mathrm{BrO}$}

Due to their high reactivity, $\mathrm{BrO}$ radicals should vanish within hours from the atmosphere. In this special event, $\mathrm{BrO}$ has apparently been transported over thousands of kilometers from its probable source region in the East Siberian and Laptev Sea towards Hudson Bay. According to the FLEXPART analysis, BrO has been transported in the lower troposphere at altitudes up to $3 \mathrm{~km}$ and therefore was only partly in contact with potential source regions at the surface after being initialised from sea salt on 25 March. A similar but smaller transport event was also described by Ridley et al. (2007). They explained an observed ODE over Hudson Bay during April 2000 by assuming long-range transport of rapidly recycled $\mathrm{BrO}$ over $1000-1500 \mathrm{~km}$ using back trajectories and a polar regional model. A 3-D model study on BrO production and ozone depletion in the Arctic boundary layer for three different Arctic stations by Zhao et al. (2008) also indicated that local ozone destruction seems to be less important than transport of ozone depleted and $\mathrm{BrO}$ enriched air masses. This confirms the importance of transport processes for ozone depletion events and possibly also bromine compounds released in bromine explosions. Nevertheless ozone depleted air masses could also be transported over long distances after in situ ozone destruction, due to the lack of ozone production processes in the polar boundary layer.

In the potential $\mathrm{BrO}$ source region, high wind speeds dominated during the release process as well as during the 
complete transport event. High wind speeds and blowing snow prevalent during an ODE were also observed in the Antarctic at Halley station by Jones et al. (2009) and could be linked to a BrO event observed by SCIAMACHY in the Weddell Sea. That case study suggests that high wind speeds and possibly also blowing snow (Yang et al., 2008) can provide a mechanism for the release and recycling of $\mathrm{BrO}$ in addition to the more classical ozone depletion events which are linked to low wind speed and a shallow boundary layer. Additionally high wind speeds are also accompanied by the formation of leads and polynyas on which young sea ice with a high salinity can form. The movement of the BrO plume studied here agrees with the pattern predicted by FLEXPART model results for a passive tracer in heights up to $3 \mathrm{~km}$. For this reason, highly efficient chemical reactions have to be assumed to continually recycle $\mathrm{BrO}$, independent from altitude. For these reactions, three possibilities exist:

1. Heterogeneous reactions on particles transported with the air mass, for example aerosols, blown snow or sea salt aerosols from frost flowers. The particles should be slowly removed from the atmosphere within a few days, but a continuous presence of aerosol in the air mass could have been supported by the dominating high wind speeds during the whole $\mathrm{BrO}$ event.

2. Deposition and subsequent re-emission of bromine on the snow and ice surfaces. This grasshopping forward movement should result in a lagging of the observations behind the model predictions which only account for direct transport. This can't be validated by FLEXPART model results and GOME-2 BrO measurements and needs further systematic investigation of similar large $\mathrm{BrO}$ events.

3. Another possible explanation would be that the surfaces were already preconditioned for bromine release along the transport path and $\mathrm{BrO}$ within the apparent plume served only to initiate the release of fresh bromine from the surfaces in the bromine explosion mechanism. This could also be an explanation for higher $\mathrm{BrO}$ values in comparison to FLEXPART model results observed north of Hudson Bay.

No firm conclusions can be drawn on the recycling mechanisms from the satellite data alone. However, the good agreement between transport calculation below $3 \mathrm{~km}$ and observations as well as the relatively constant total $\mathrm{BrO}$ amount observed over several days and the high wind speeds involved suggest that at least for this event, recycling within the air mass is more important than surface reactions. This is also supported by backward trajectory calculations, which indicate an upward transport from the potential source region into higher altitudes up to $3 \mathrm{~km}$ at the beginning of the event.

In a recent study, Jones et al. (2010) investigated historical data sets of ozone profiles in the Antarctic and found evidence of elevated layers of low ozone linked to low pressure systems. The Arctic $\mathrm{BrO}$ event discussed here appears to follow a similar pattern with initialisation by high winds in a low pressure system, upward movement and subsequent transport.

\section{Summary and conclusions}

In March 2007 a large $\mathrm{BrO}$ event was observed using GOME-2 data over many days in the Arctic, reaching maximum tropospheric column values around $1.5 \times 10^{14} \mathrm{molec} / \mathrm{cm}^{2}$. Full activation of the $\mathrm{BrO}$ took place between two GOME-2 overpasses which were $24 \mathrm{~h}$ apart. The BrO plume originated from two different source regions and over the next few days moved several thousand kilometers towards Hudson Bay. The initialisation and movement of the event was linked to a cyclone with very high surface wind speeds. Using the particle dispersion model FLEXPART and a passive tracer initialised in different altitudes with the $\mathrm{BrO}$ observations from the first day, the satellite $\mathrm{BrO}$ values from subsequent days could be explained by transport processes between the surface and $3 \mathrm{~km}$. While initialisation in this altitude range provides the best agreement between model and measurements, vertical wind shear was small and the difference to runs initialised in the surface layer and between 5 and $7 \mathrm{~km}$ altitude is small.

Comparisons of stratospheric corrected $\mathrm{BrO}$ columns with total ozone and tropopause heights as well as backward trajectories from the area of initialisation indicate, that in this special event, $\mathrm{BrO}$ or precursors were probably initialised at the surface during high wind speeds, mixed upwards in the low pressure system and subsequently transported horizontally. In spite of the low tropopause heights present during the event, no indication was found for a stratospheric intrusion bringing $\mathrm{BrO}$ rich stratospheric air into the troposphere. However, backward trajectories indicate upward movement just before the start of the event. The effect of the increase in stratospheric $\mathrm{BrO}$ column through the low tropopause is thought to be corrected by the stratospheric $\mathrm{BrO}$ climatology used. Some remaining impact can not be excluded, but is believed to be small. The magnitude of the observed $\mathrm{BrO}$ column cannot be explained by tropopause height changes alone.

Due to the short lifetime of BrO, highly efficient recycling processes should be involved within the transported air masses to sustain the observed high $\mathrm{BrO}$ levels over this long period, no matter in which height interval the transport takes place. The combination of high wind speeds and rapid movement of the $\mathrm{BrO}$ plume suggests that recycling of $\mathrm{BrO}$ took place within the air mass, e.g. on aerosols and/or snowflakes rather than on the surface. The rapid activation of the $\mathrm{BrO}$ followed by several days of relatively constant total $\mathrm{BrO}$ amounts further supports the interpretation of the event as a combination of an initial release with subsequent transport 
of BrO. To identify the recycling mechanism and probable source regions of $\mathrm{BrO}$ targeted in situ aircraft investigations of $\mathrm{BrO}$ events are needed.

The magnitude of the $\mathrm{BrO}$ event discussed here both in size and $\mathrm{BrO}$ columns and its link to a strong low pressure system underline the importance of dynamic $\mathrm{BrO}$ events. How relevant this type of $\mathrm{BrO}$ activation is in comparison to other $\mathrm{BrO}$ events at stable conditions needs to be investigated in more detail.

The observed long range transport of $\mathrm{BrO}$ supports earlier conclusions that low ozone events and $\mathrm{BrO}$ observed at coastal stations can originate from far away bromine sources in the Arctic Sea ice. An efficient recycling of $\mathrm{BrO}$ over several days also indicates long-range transport of sea-salt aerosols in the cyclone from East Siberia to Hudson Bay. This transport is also important for the analysis of in situ measurements and the interpretation of ice cores taken far away from sea salt sources.

Acknowledgements. We acknowledge the Norwegian Research Council for funding in the framework of POLARCAT and the Deutsche Forschungsgemeinschaft DFG for funding this work through the SALT project. Temperature and wind data have been provided by ECMWF. We would like to thank Dr. Andreas Dörnbrack from DLR Oberpfaffenhofen for providing ECMWF tropopause height data analysis, the NOAA Air Resources Laboratory (ARL) for the provision of the HYSPLIT transport and dispersion model and two anonymous reviewers for thought provoking and helpful suggestions and comments.

Edited by: O. Cooper

\section{References}

Afe, O. T., Richter, A., Sierk, B., Wittrock, F., and Burrows, J. P.: BrO emission from volcanoes: A survey using GOME and SCIAMACHY measurements, Geophys. Res. Lett., 31, L24113, doi:10.1029/2004GL020994, 2004.

Barrie, L. A., Bottenheim, J. W., Schnell, R. C., Crutzen, P. J., and Rasmussen, R. A.: Ozone destruction and photochemical reactions at polar sunrise in the lower Arctic atmosphere, Nature, 334, 138-141, 1988.

Barrie, L. A., den Hartog, G., Bottenheim, J. W., and Landsberger, S.: Anthropogenic aerosols and gases in the lower troposphere at Alert, Canada in April 1986, J. Atmos. Chem., 9, 101-127, 1989.

Bottenheim, J. W., Gallant, A. G., and Brice, K. A.: Measurements of $\mathrm{NO}_{Y}$ species and $\mathrm{O}_{3}$ at $82^{\circ} \mathrm{N}$ latitude, Geophys. Res. Lett., 13(2), 113-116, 1986.

Callies, J., Corpaccioli, E., Hahne, A., Lefebvre, A.: GOME-2 Metop's second-generation sensor for operational ozone monitoring, ESA Bulletin-European Space Agency, 102, 28-36, 2000.

Coldewey-Egbers, M., Weber, M., Lamsal, L. N., de Beek, R., Buchwitz, M., and Burrows, J. P.: Total ozone retrieval from GOME UV spectral data using the weighting function DOAS approach, Atmos. Chem. Phys., 5, 1015-1025, doi:10.5194/acp5-1015-2005, 2005.

Domine, F., Taillandier, A. S., Simpson, W. R., and Severin, K.: Specific surface area, density and microstructure of frost flowers,
Geophys. Res. Lett., 32, L13502, doi:10.1029/2005GL023245, 2005.

Draxler, R. R. and Rolph, G. D.: HYSPLIT (HYbrid Single-Particle Lagrangian Integrated Trajectory) Model access via NOAA ARL READY Website (http://ready.arl.noaa.gov/HYSPLIT. php). NOAA Air Resources Laboratory, Silver Spring, MD, USA, 2010.

Frieß, U., Hollwedel, J., König-Langlo, G., Wagner, T., and Platt, U.: Dynamics and chemistry of tropospheric bromine explosion events in the Antarctic coastal region, J. Geophys. Res., 109, D06305, doi:10.1029/2003JD004133, 2004.

Hausmann, M., and Platt, U.: Spectroscopic measurement of bromine oxide and ozone in the high Arctic during Polar Sunrise Experiment 1992, J. Geophys. Res., 99(D12), 25399-25413, 1994.

Hoinka, K. P., Claude, H., and Köhler, U.: On the correlation between tropopause pressure and ozone above central Europe, Geophys. Res. Lett., 23(14), 17531756, 1996.

Hönninger, G. and Platt, U.: Observations of $\mathrm{BrO}$ and its vertical distribution during surface ozone depletion at Alert, Atmos. Environ., 36, 2481-2489, 2002.

Jones, A. E., Anderson, P. S., Begoin, M., Brough, N., Hutterli, M. A., Marshall, G. J., Richter, A., Roscoe, H. K., and Wolff, E. W.: $\mathrm{BrO}$, blizzards, and drivers of polar tropospheric ozone depletion events, Atmos. Chem. Phys., 9, 4639-4652, doi:10.5194/acp-94639-2009, 2009.

Jones, A. E., Anderson, P. S., Wolff, E. W., Roscoe, H. K., Marshall, G. J., Richter, A., Brough, N., and Colwell, S. R.: Vertical structure of Antarctic tropospheric ozone depletion events: characteristics and broader implications, Atmos. Chem. Phys. Discuss., 10, 8189-8246, doi:10.5194/acpd-10-8189-2010, 2010.

Kaleschke, L., Richter, A., Burrows, J. P., Afe, O., Heygster, G., Notholt, J., Rankin, A. M., Roscoe, H. K., Hollwedel, J., Wagner, T., and Jacobi, H.-W.: Frost flowers on sea ice as a source of sea salt and their influence on tropospheric halogen chemistry, Geophys. Res. Lett., 31, L16114, doi:10.1029/2004GL020655, 2004.

Kreher, K., Johnston, P. V., Wood, S. W., Nardi, B., and Platt, U.: Ground-based measurements of tropospheric and stratospheric $\mathrm{BrO}$ at Arrival Heights, Antarctica, Geophys. Res. Lett., 24(23), 3021-3024, 1997.

Lehrer, E., Wagenbach, D., and Platt, U.: Aerosol chemical composition during tropospheric ozone depletion at Ny Alesund/Svalbard, Tellus, 49B, 486-495, 1997.

McConnell, J. C., Henderson, G. S., Barrie, L., Bottenheim, J., Niki, H., Langford, C. H., and Templeton, E. M. J.: Photochemical bromine production implicated in Arctic boundary-layer ozone depletion, Nature, 355, 150-152, 1992.

Murayama, S., Nakazawa, T., Tanaka, M., Aoki, S., and Kawaguchi, S.: Variations of tropospheric ozone concentration over Syowa Station, Antarctica, Tellus 44B, 262-272, 1993.

Obbard, R. W., Roscoe, H. K., Wolff, E. W., and Atkinson, H. M.: Frost flower surface area and chemistry as a function of salinity and temperature, J. Geophys. Res., 114, D20305, doi:10.1029/2009JD012481, 2009.

Oltmans, S. J., Surface Ozone Measurements in Clean Air, J. Geophys. Res., 86(C2), 1174-1180, 1981.

Perovich, D. K. and Richter-Menge, J. A.: Surface characteristics of lead ice, J. Geophys. Res., 99(C8), 16341-16350, 1994. 
Platt, U.: Differential optical absorption spectroscopy (DOAS), in: Air Monitoring by Spectroscopic Techniques, Chem. Anal. Ser., edited by: Sigrist, M. W., John Wiley, New York, USA, 127, 27-84, 1994.

Platt, U. and Lehrer, E.: Arctic Tropospheric Ozone Chemistry, ARCTOC, Final Report of the EU-Project NO. EV5V-CT930318, 1996.

Platt, U., Wagner, T.: Satellite mapping of enhanced BrO concentrations in the troposphere. Nature 395, 486-490, 1998.

Rankin, A. M., Wolff, E. W., and Martin, S.: Frost flowers: Implications for tropospheric chemistry and ice core interpretation, J. Geophys. Res., 107(D23), 4683, doi:10.1029/2002JD002492, 2002.

Richter, A., Wittrock, F., Eisinger, M., and Burrows, J. P.: GOME observations of tropospheric $\mathrm{BrO}$ in northern hemispheric spring and summer 1997, Geophys. Res. Lett., 25(14), 2683-2686, 1998.

Richter, A., Wittrock, F., Ladstätter-Weißenmayer, A., and Burrows, J. P.: GOME measurements of stratospheric and tropospheric BrO, Adv. Space Res., 29, 1667-1672, 2002.

Ridley, B. A., Zeng, T. Wang, Y., Atlas, E. L., Browell, E. V., Hess, P. G., Orlando, J. J., Chance, K., and Richter, A.: An ozone depletion event in the sub-arctic surface layer over Hudson Bay, Canada, J. Atmos. Chem., 57(3), 255-280, 2007.

Rozanov, A., Bovensmann, H., Bracher, A., Hrechanyy, S., Rozanov, V., Sinnhuber, M., Stroh, F., and Burrows, J. P.: $\mathrm{NO}_{2}$ and $\mathrm{BrO}$ vertical profile retrieval from SCIAMACHY limb measurements: Sensitivity studies, Advances in Space Research, Atmospheric Remote Sensing: Earth's Surface, Troposphere, Stratosphere and Mesosphere I, 36(5), 846-854, 2005.

Sander, R., Burrows, J., and Kaleschke, L.: Carbonate precipitation in brine - a potential trigger for tropospheric ozone depletion events, Atmos. Chem. Phys., 6, 4653-4658, doi:10.5194/acp-64653-2006, 2006.

Schubert, S. D. and Munteanu, M. J.: An Analysis of Tropopause Pressure and Total Ozone Correlations, Mon. Weather Rev., 116, 569582, 1988.

Simpson, W. R., Carlson, D., Hönninger, G., Douglas, T. A., Sturm, M., Perovich, D., and Platt, U.: First-year sea-ice contact predicts bromine monoxide $(\mathrm{BrO})$ levels at Barrow, Alaska better than potential frost flower contact, Atmos. Chem. Phys., 7, 621-627, doi:10.5194/acp-7-621-2007, 2007.

Stohl, A., Hittenberger, M., and Wotawa, G.: Validation of the Lagrangian particle dispersion model FLEXPART against large scale tracer experiments. Atmos. Environ. 32, 4245-4264, 1998.
Stohl, A., Forster, C., Frank, A., Seibert, P., and Wotawa, G.: Technical note: The Lagrangian particle dispersion model FLEXPART version 6.2, Atmos. Chem. Phys., 5, 2461-2474, 2005.

Sturges, W. T., Sullivan, C. W., Schnell, R. C., Heidt, L. E., and Pollock, W. H.: Bromoalkane production by Antarctic ice algae, Tellus 45B, 120-126, 1993.

Theys, N., Van Roozendael, M., Errera, Q., Hendrick, F., Daerden, F., Chabrillat, S., Dorf, M., Pfeilsticker, K., Rozanov, A., Lotz, W., Burrows, J. P., Lambert, J.-C., Goutail, F., Roscoe, H. K., and De Maziẽre, M.: A global stratospheric bromine monoxide climatology based on the BASCOE chemical transport model, Atmos. Chem. Phys., 9, 831-848, 2009.

Theys, N., Van Roozendael, M., Dils, B., Hendrick, F., Hao, N., and De Mazière, M.: First satellite detection of volcanic bromine monoxide emission after the Kasatochi eruption, Geophys. Res. Lett., 36, L03809, doi:10.1029/2008GL036552, 2009.

Wagner, T., Leue, C., Wenig, M., Pfeilsticker, K., and Platt, U.: Spatial and temporal distribution of enhanced boundary layer $\mathrm{BrO}$ concentrations measured by the GOME instrument aboard ERS2, J. Geophys. Res., 106(D20), 24225-24235, 2001.

Wagner, T., Ibrahim, O., Sinreich, R., Frieß, U., von Glasow, R., and Platt, U.: Enhanced tropospheric BrO over Antarctic sea ice in mid winter observed by MAX-DOAS on board the research vessel Polarstern, Atmos. Chem. Phys., 7, 3129-3142, 2007.

Weber, M., Lamsal, L. N., and Burrows, J. P.: Improved SCIAMACHY WFDOAS total ozone retrieval: Steps towards homogenising long-term total ozone datasets from GOME, SCIAMACHY and GOME-2, Proc. ENVISAT Symposium 2007, Montreux, Switzerland, 23-27 April 2007, ESA SP 636, July 2007.

Wessel, S., Herber, A., Gernandt, H., Aoki, S., Winkler, P., Weller, R., and Schrems, O.: Irregular ozone depletion events in the Antarctic troposphere recorded at Neumayer Station in 1992 and 1993, Mem. Natl. Inst. Pol. Res., Spec. Issue, 52, 89-101, 1998.

Vogt, R., Crutzen, P. J., and Sander, R.: A mechanism for halogen release from sea-salt aerosol in the remote marine boundary layer, Nature, 383, 327-330, 1996.

Yang, X., Pyle, J. A., and Cox, R. A.: Sea salt aerosol production and bromine release: Role of snow on sea ice, Geophys. Res. Lett., 35, L16815, doi:10.1029/2008GL034536, 2008.

Zhao, T. L., Gong, S. L., Bottenheim, J. W., McConnell, J. C., Sander, R., Kaleschke, L., Richter, A., Kerkweg, A., Toyota, K., and Barrie, L. A.: A three-dimensional model study on the production of $\mathrm{BrO}$ and Arctic boundary layer ozone depletion, J. Geophys. Res., 113, D24304, doi:10.1029/2008JD010631, 2008. 